\title{
Risk Perception of International Medical Students About Coronavirus (COVID-19) in China and Their Willingness to Fly Back
}

This article was published in the following Dove Press journal: Risk Management and Healthcare Policy

\author{
Muhammad Ishfaq Ahmad (D) ${ }^{1,2}$ \\ Muhammad Akram Naseem ${ }^{2}$ \\ Ramiz Ur Rehman ${ }^{2}$ \\ Weiqing Zhuang' \\ Rizwan $\mathrm{Ali}^{2}$ \\ Muhammad Suhaib Manzoor ${ }^{2}$ \\ 'School of Internet Economics and \\ Business, Fujian University of Technology, \\ Fuzhou, Fujian, People's Republic of \\ China; ' 2 Lahore Business School, The \\ University of Lahore, Lahore, Punjab, \\ Pakistan
}

\begin{abstract}
Purpose: This study aimed to investigate the willingness of international medical students enrolled in Chinese universities to return to their home countries based on their risk perception of the recent outbreak of the novel coronavirus disease (COVID-19).

Materials and Methods: A well-structured questionnaire was incorporated into the WeChat survey, a special feature within this mobile application, similar to Google Docs. The questionnaire was sent to 1190 international medical students across China between January 1, 2020 and May 15, 2020. A total of 897 completed questionnaires were returned, indicating a $75 \%$ response rate.

Results: The survey findings show that the risk perception of international medical students about COVID-19 was low because of the strong preventive measures taken by the Chinese government against COVID-19. Moreover, they were willing to stay in China until the completion of their degrees. In contrast, students who have completed their degrees were willing to return home immediately if possible.

Conclusion: These findings are of serious concern for developing countries where they come from because their return to their home countries may cause an epidemic outbreak in those regions.
\end{abstract}

Keywords: strong preventive, serious concern, developing countries, epidemic outbreak

\section{Introduction}

In December 2019, in Wuhan, Hubei province, China, pneumonia of unknown cause in a cluster of patients was linked to a seafood wholesale market. Wuhan was declared the epicenter of an outbreak of a disease known as the novel coronavirus disease 2019 (COVID-19). The disease demanded intense attention not only within China but internationally. Because COVID-19 patients also traveled internationally, on May 31, 2020, 5,934,936 confirmed cases were reported globally (WHO Situation Report 30th May 2020) ${ }^{1}$ (World Health Organization, 2019). Most cases outside China were transmitted from the epidemic epicenter, ie, Wuhan. The first case of the United States (US) was confirmed on 20th January 2020; a 35-year-old male had a Wuhan travel history. ${ }^{2}$ Only limited studies have been conducted on the mobility of people and infectious diseases. International travelers are the microbial agents that import different diseases into their areas of travel. ${ }^{3}$ They also predicted that a global village in the 20th century provides more opportunities for disease emergence and transmission. This is precisely what happened in the case of COVID-19 as the first case of COVID-19 in New York was brought in mainly from Europe, not Asia. ${ }^{4}$
Correspondence: Weiqing Zhuang School of Internet Economics and Business, Fujian University of Technology, No. 33 Xueyuan Road, University Town, Minhou, Fuzhou, Fujian, People's Republic of China

Tel +86-I38050I 2485

Email zmakio@aliyun.com
Risk Management and Healthcare Policy 2021:14 503-510

submit your manuscript DovePress if in $>$ 
Similarly, the movement of populations shapes the patterns and distribution of infectious diseases globally. ${ }^{5}$ $\mathrm{He}$ also noted that worldwide connectedness and mobility facilitates the spread of diseases. In Wuhan, travel quarantine delayed the overall epidemic progression to Mainland China by only 3-5 days but had a more marked effect at the international level. Despite cases, importations were reduced by nearly $80 \%$ until mid-February. ${ }^{6}$ Similarly, the impact of human mobility and control measures on the COVID-19 epidemic in China and the spatial distribution of COVID-19 cases in China could be suitably explained based on human mobility data. ${ }^{7}$

The rapid transmission of severe acute respiratory syndrome coronavirus COVID-19 in China and globally in the past 6 months is a matter of great concern. The international community residing in China for different purposes showed panic and frustration despite the aggressive preventive measures taken by the Chinese government against the deadly virus. The majority of the international community in China consists of international students from different regions of the world. According to the Ministry of Education (MOE) of China, the number of international students is approximately $4,92,185 .{ }^{8}$ Among these international students, $59.95 \%$ are from Asia, $16.75 \%$ from Africa, $14.96 \%$ from Europe, $7.26 \%$ from America, and 1.27\% from Oceania (Ministry of Education China, 2019). ${ }^{8}$ The countries are taking initiatives at the government level to bring back their citizens from China on a priority basis. This may cause the importation of COVID-19 to their home countries. ${ }^{3,6,7}$ It will be interesting to investigate how international medical students assess this problematic situation and what kind of decision they will take, whether to return to their home countries immediately or stay in China and wait for the end of this outbreak. For this purpose, an online survey was conducted to assess international medical students' willingness to return to their home countries based on the risk perception of the COVID-19 outbreak in China. If the students show a willingness to return to their home countries, it may rapidly create an epidemic of the deadly disease in their residence regions. The following sections explain the survey and data collection methods, as well as summarize the risk perception.

\section{Materials and Methods}

The survey elicited information on international medical students' COVID-19 risk perception and their willingness to return to their home countries if possible.

\section{Methods}

International medical students studying in China were asked to respond to a structured questionnaire on their willingness to fly back to their home countries based on their risk perception about the recent outbreak of COVID-19 (see Supplementary material). The measurement of risk perception is a complex task and based on various factors. Therefore, the survey included two aspects of risk; one is the magnitude of the risk, based on the probability measure of the spread and mortality rate of epidemic outbreak in the region within a month. The respondents were asked a single question to determine whether the magnitude of the said outbreak is high or low based on the probability calculation of its spread and mortality rate. The second aspect was the risk perception regarding the outbreak based on the psychometric framework proposed by Slovic. ${ }^{9}$ Several researchers, such as $\mathrm{Liu}^{10}$ used a similar framework to measure the risk perception about SARS, and the same framework was employed to test the broad concept of risk perception. ${ }^{11}$ The proposed psychometric framework was based on severity, danger knowledge, personal control, concern, and safety of the epidemic outbreak. The respondents were asked a single question regarding each element of risk perception. A sample question is shown below.

"I have enough knowledge of how nCovid-19 spread."

"No Knowledge 12345 Much Knowledge"

Each question was further measured on a five-point Likert scale. The willingness to fly back to their home countries was asked through a dichotomous question with an option of Yes or No. The survey's remaining questions were about the demographics of the respondents and their opinion about the socioeconomic situation after the COVID-19 outbreak.

\section{Procedure}

The structured questionnaire was incorporated into the WeChat survey, a special feature within this mobile application, similar to Google Docs. Next, the link to the questionnaire was sent to the students. This structured questionnairebased survey was conducted between January 1, 2020, and May 15, 2020. Owing to the government's containment measures, it was challenging to meet the students personally to obtain the data. Therefore, the study adopted an online medium to collect data from international students in China.

\section{Participants}

The study employed the non-probabilistic sampling technique, such as Toan Luu Duc Huynh. ${ }^{12}$ The target population comprised the international medical student 
Table I Sample Distribution

\begin{tabular}{|l|l|l|l|l|}
\hline S. No. & Province/City & Number of Students & Sample & Sample in \% \\
\hline 1 & Hubei/Wuhan & 21,371 & 269 & 30 \\
2 & Guangdong & 22,034 & 134 & 15 \\
3 & Beijing & 80,786 & 54 & 6 \\
4 & Shanghai & 61,400 & 72 & 8 \\
5 & Jiangsu & 45,778 & 54 & 6 \\
6 & Zhejiang & 38,190 & 72 & 8 \\
7 & Liaoning & 27,879 & 63 & 7 \\
8 & Tianjin & 23,691 & 81 & 9 \\
9 & Yunnan & 19,311 & 72 & 8 \\
10 & Shandong & 19,078 & 26 & 3 \\
\hline Total & Total & 359,518 & 897 & 100 \\
\hline
\end{tabular}

Note: Data sourced from Ministry of Education, P.R China. ${ }^{8}$

community of China. Tables 1 and 2 explain the profile and demographic data of the respondents. The questionnaire was sent to 1190 international students across China through WeChat, a social networking software widely used in Mainland China and ranked the fifth most used software (Business of Apps) in the world. Initially, 1200 questionnaires were distributed among medical students, 972 total questionnaires returned, and 75 were ignored due to incomplete responses. A total of 897 completed questionnaires were used, indicating a $75 \%$ response rate for final analysis. A sample profile is presented in Table 1.

As Wuhan city, Hubei province, was the epicenter of the COVID-19 outbreak, the study attempted to obtain more international students' responses in this region. The sample consisted of $30 \%$ of respondents from Hubei, the outbreak epicenter, and 15\% from Guangdong, the province with the second largest number of patients affected by the deadly virus. More international students reside in Guangdong compared to other provinces. Overall, the study covered 10 provinces where international students reside. Summary statistics and dummy variables description are shown in Table 2.

Risk perception is complex and influenced by several qualitative factors, such as the extent to which risk is uncontrollable, unknown, and fatal. ${ }^{9}$ These factors ultimately influence the decision to return to their home

Table 2 Summary Statistics and Description of Dummy Variables

\begin{tabular}{|l|l|l|l|l|}
\hline Variables & Nature & Description & Yes & No \\
\hline Risk & Dummy & I if risk per month $=3 * 10^{-6}, 0$ if $3 * 10^{-2}$ & $83 \%$ \\
\hline Mortality risk & Dummy & I if conditional morality risk is $0.20,0$ if 0.10 & $47 \%$ & $53 \%$ \\
\hline Gender & Dummy & I if male, 0 if female & $61 \%$ & $39 \%$ \\
\hline Marital status & Dummy & I if married, 0 if otherwise & $33 \%$ & $67 \%$ \\
\hline Residence & Dummy & I if Hubei province, 0 if otherwise & $30 \%$ & $70 \%$ \\
\hline Religious belief & Dummy & I if the respondent has any religion, 0 if otherwise & $65 \%$ & $35 \%$ \\
\hline Mask & Dummy & I if the respondent wears mask outside, 0 if otherwise & $91 \%$ & $9 \%$ \\
\hline Flu shot & Dummy & I if the respondent had flu in 6 months, 0 if otherwise & $16 \%$ & $84 \%$ \\
\hline Willingness to return & Dummy & I if respondent is willing to return to home country, 0 if otherwise & $39 \%$ & $61 \%$ \\
\hline Education & Categorical & $\begin{array}{l}\text { Graduation } \\
\text { Master } \\
\text { PhD } \\
\text { Post Doc }\end{array}$ & $\begin{array}{l}45 \% \\
32 \%\end{array}$ \\
\hline
\end{tabular}


country to reduce the risk. ${ }^{13}$ The magnitude of risk is based on the probability calculation of the spread of the outbreak among the residents in a month. The probability of COVID-19 spreading among the residents in a month was taken as $3 * 10^{-3}$ (Liu et al 2004), ie, the chance of infecting three people (3) out of 100,000 people month. This probability is reckoned as a low-risk magnitude. The majority of the respondents $(83 \%)$ believed that the magnitude of risk in COVID-19 spread was $3 * 10^{-6}$, which shows that their perception of the risk magnitude was low. The results confirmed the results of the study among medical students. ${ }^{14}$ As it is evident that the Chinese government is taking serious steps toward its citizens' safety by postponing the new semester generally, ${ }^{15}$ and paying particular attention to international students to keep them safe from this virus, $53 \%$ of the respondents believed less mortality risk.

Moreover, $61 \%$ of the respondents were male, and $67 \%$ were unmarried, indicating that most international medical students were young. Furthermore, 55\% of the respondents had a bachelor's degree, showing they entered university from college. Around 30\% of our respondents were from Hubei province, the province with the most infection cases. Interestingly, most of the students there wanted to return to their home country if they were provided a chance.

Apart from the dummy variables, categorical variables are presented in Table 3.

We measured the abovementioned variables through a five-point Likert scale. Personal control indicates the condition under which the individual can modify the risk of COVID-19 infection. Knowledge implies the respondent's knowledge of COVID-19 transmission, and safety describes the respondent's perception of whether he/she is safe in China. The respondents were aged between 21 and 39 years, increasing their confidence that they have a stronger immune system as they are young, have more chances to be safe, and be treated if they are infected with COVID-19. ${ }^{16}$ Moreover, severity and economy describe whether international medical students think COVID-19 will severely affect China and its economy. Willingness to return was measured through a dummy variable by asking the respondents whether they would welcome a chance or obtain approval from their school to return to their home country. The respondents believe the virus is controllable, as evident in the tables presented, and therefore, they performed all measures to prevent infection from this virus, as shown in their knowledge.

Table 3 Summary Statistics and Description of Categorical Variables

\begin{tabular}{|c|c|c|c|c|c|c|}
\hline Variables & Nature & Description & Min & Max & Mean & Std \\
\hline Age & In years & Students age in years & 21 & 39 & 28 & 2.14 \\
\hline Family size & $\begin{array}{l}\text { No. of } \\
\text { persons in a } \\
\text { family }\end{array}$ & Family members & 1 & 7 & 2 & 2.4 \\
\hline $\begin{array}{l}\text { Health } \\
\text { status }\end{array}$ & Categorical & $\begin{array}{l}\text { Perceived health status ranges from extremely poor to excellent on a five-point } \\
\text { Likert scale }\end{array}$ & I & 5 & 4.21 & 1.05 \\
\hline Economy & Categorical & $\begin{array}{l}\text { Respondent perception about the serious impact of COVID-19 on China's } \\
\text { economy ranges from not at all to extremely serious on a five-point Likert scale }\end{array}$ & I & 5 & 4.48 & 0.78 \\
\hline Study & Categorical & $\begin{array}{l}\text { Perception that COVID-19 will influence their studies ranges from not at all to } \\
\text { serious influence measured through a five-point Likert scale }\end{array}$ & 1 & 5 & 3.46 & 1.21 \\
\hline Severity & Categorical & $\begin{array}{l}\text { Severity of COVID-19 in China ranges from not at all serious to extremely serious } \\
\text { measured through a five-point Likert scale }\end{array}$ & I & 5 & 4.67 & 1.76 \\
\hline Danger & Categorical & $\begin{array}{l}\text { Effects of COVID-19 risk on respondent's life range from not at all to extremely } \\
\text { serious measured through a five-point Likert scale }\end{array}$ & 1 & 5 & 4.41 & 1.95 \\
\hline Knowledge & Categorical & $\begin{array}{l}\text { Knowledge on how COVID-19 spreads from little knowledge to much knowledge } \\
\text { measured through a five-point Likert scale }\end{array}$ & I & 5 & 3.88 & 0.76 \\
\hline $\begin{array}{l}\text { Personal } \\
\text { control }\end{array}$ & Categorical & $\begin{array}{l}\text { Degree of personal control of COVID-19 risk ranges from not at all to extremely } \\
\text { controllable measured through a five-point Likert scale }\end{array}$ & I & 5 & 4.01 & 1.45 \\
\hline Concern & Categorical & $\begin{array}{l}\text { Concern about COVID-19 infection ranges from not at all to extremely concerned } \\
\text { measured through a five-point Likert scale }\end{array}$ & I & 5 & 4.43 & 1.89 \\
\hline Safety & Categorical & $\begin{array}{l}\text { Perception of safety in China ranges from not at all to fully safe measured through a } \\
\text { five-point Likert scale }\end{array}$ & I & 5 & 4.41 & 0.75 \\
\hline
\end{tabular}


Table 4 Willingness to Return Regression Analysis

\begin{tabular}{|c|c|c|c|c|c|c|c|c|c|c|c|c|}
\hline \multirow[t]{2}{*}{ Variables } & \multicolumn{4}{|l|}{ I } & \multicolumn{4}{|l|}{2} & \multicolumn{4}{|l|}{3} \\
\hline & B & SE & Wald & OR & B & SE & Wald & OR & B & SE & Wald & OR \\
\hline Constant & 9.56 & 1.66 & 33.09 & 0.00 & -3.15 & 1.33 & 8.66 & 0.02 & $-|.8|$ & 1.07 & 2.86 & 0.16 \\
\hline Sex & 0.53 & 0.55 & 0.93 & 1.70 & & & & & & & & \\
\hline Marital status & $0.23^{* *}$ & 0.09 & 6.53 & 1.26 & & & & & & & & \\
\hline Age & $0.07^{* *} *$ & 0.03 & 5.44 & 1.07 & & & & & & & & \\
\hline Family size & $0.09 * *$ & 0.04 & 5.06 & 1.09 & & & & & & & & \\
\hline Education & $0.07^{* * *}$ & 0.02 & 12.25 & 1.07 & & & & & & & & \\
\hline Health status & & & & & 0.05 & 0.07 & 0.51 & 1.05 & & & & \\
\hline Study & & & & & $-0.18^{* *}$ & 0.04 & 20.25 & 0.84 & & & & \\
\hline Severity & & & & & 0.04 & 0.05 & 0.64 & 1.04 & & & & \\
\hline Danger & & & & & 0.06 & 0.11 & 0.29 & 1.06 & & & & \\
\hline Knowledge & & & & & 0.05 & 0.07 & 0.51 & 1.05 & & & & \\
\hline Personal control & & & & & $-0.23^{*}$ & 0.11 & 4.37 & 0.79 & & & & \\
\hline Concern & & & & & $0.24^{*}$ & 0.16 & 2.25 & 1.27 & & & & \\
\hline Safety & & & & & $-0.70 * *$ & 0.08 & 76.56 & 2.01 & & & & \\
\hline Mortality & & & & & & & & & $-0.3 I^{* *}$ & 0.13 & 5.68 & 1.36 \\
\hline Risk & & & & & & & & & $-0.21 * * *$ & 0.11 & 3.64 & 1.23 \\
\hline Residence & & & & & & & & & $0.25 * * *$ & 0.14 & 3.19 & 1.38 \\
\hline Religion & & & & & & & & & $0.23 * *$ & 0.12 & 3.67 & 1.26 \\
\hline Flu shot & & & & & & & & & I.I & 1.05 & 1.09 & 3.00 \\
\hline \multirow{2}{*}{\multicolumn{2}{|c|}{$\begin{array}{l}\text { Province/City } \\
\text { Model significance }\end{array}$}} & \multirow{2}{*}{\multicolumn{3}{|c|}{$\begin{array}{l}\text { Yes } \\
59.60(0.00)^{* * *}\end{array}$}} & \multirow{2}{*}{\multicolumn{4}{|c|}{$\begin{array}{l}\text { Yes } \\
67.87(0.00)^{* * * *}\end{array}$}} & \multirow{2}{*}{\multicolumn{4}{|c|}{$\begin{array}{l}\text { Yes } \\
74.39(0.00)^{* * *}\end{array}$}} \\
\hline & & & & & & & & & & & & \\
\hline \multicolumn{13}{|l|}{ Model summary } \\
\hline \multirow{3}{*}{\multicolumn{2}{|c|}{$\begin{array}{l}-2 \text { log likelihood } \\
\text { Cox and Snell R2 } \\
\text { Nagelkerke R2 }\end{array}$}} & \multicolumn{3}{|c|}{117.25} & \multicolumn{4}{|l|}{279.23} & \multicolumn{4}{|l|}{365.99} \\
\hline & & \multicolumn{3}{|l|}{0.08} & \multicolumn{4}{|l|}{0.15} & \multicolumn{4}{|l|}{0.17} \\
\hline & & \multicolumn{3}{|l|}{0.07} & \multicolumn{4}{|l|}{0.17} & \multicolumn{4}{|l|}{0.19} \\
\hline
\end{tabular}

Note: $* * * 1 \%, * * 5 \%$ and $* 10 \%$ level of significance.

Logistic regression models were applied due to the dependent variable's binary nature, ie, willingness to fly back, to achieve the objectives of this study.

\section{Results and Discussion}

Three models were estimated using the maximum likelihood methods in Table 4. The first model included demographic variables and their impact on willingness to fly back, column 1. The second model added the perception of risk variables to a willingness to fly, column 2. The third model included the magnitude of risk variables and other variables to estimate respondents' willingness to fly back, column 3 . Willingness to return to the home country was estimated to increase with marital status, age, and family size. The co-efficient of marital status was higher, implying that married students were more likely to return if they get permission from their respective schools. They were more concerned about their families, as evident $\left(0.09^{* *}\right)$. The co-efficient of education was positive and significant (0.07) as evident. ${ }^{17}$ It shows that students enrolled in higher degrees were more willing to stay in China, as compared to those who were enrolled in bachelor's degrees, to complete their degrees and then return to their home countries. Students enrolled in Ph.D. or Post-doc were considered higher degree students. Their higher education makes it irrational to return to their home countries because they may have higher education edge to find a job easier than the bachelor level students.

In the second model, the risk perception variables about COVID-19 were considered explanatory variables and willingness to fly back as a dependent variable. Moreover, health status and study were also regarded as explanatory variables in the model. The co-efficient of the study was negative and significant. This result shows that if students think that their studies will be affected by 
COVID-19, they will prefer to stay in China. Most of the risk perception variables were positive but insignificant, except personal control and safety. The co-efficient of personal control was negative and significant $(-0.23)$ and confirmed the results by Huynh. ${ }^{18}$ These personal controls can also be explained by the protection motivation theory (PMT) that states that self-protection plays a key role in disease protection as Floyd, Donna L. ${ }^{19}$ According to PMT theory, our results showed that high personal control of COVID-19 would decrease the probability of a student deciding in favor of willingness to fly back home. Further, the safety co-efficient was also negative and significant, which shows that medical students feel safe in China because of the strong preventive measures implemented by the government against the COVID-19 outbreak; therefore, there are less chances that students will go back. Students believed that COVID-19 was under control and their control measures were appropriate.

The third model included the magnitude of risk variables to estimate the willingness of students to go back. The mortality co-efficient was negative and significant $(-0.31)$, which shows that the low magnitude of mortality risk reduced the chances of medical students' willingness to return home. Further, the magnitude of spread risk was also negative and significantly related to the willingness to fly back home. It shows that the students perceived that COVID-19 had a low magnitude of spread risk; therefore, it was better to stay in China and complete their studies. However, the residence variable was positive and significantly related to the willingness to fly back home. Thus, students residing in Hubei province were more willing to fly back home compared to students living in other parts of China.

\section{Conclusion}

An online survey was conducted among the international students in China between January 1, 2020, and May 15, 2020 , to assess their willingness to fly back home based on their perceived risk regarding COVID-19. The findings showed that several steps had been undertaken in China to reduce the risk of COVID-19. Risk perception variables suggest that COVID-19 was of great concern, respondents were knowledgeable of the disease, and it was possible to control it through personal measures. Results confirmed the study of Huynh ${ }^{20}$ knowledge significantly matters for risk perception. Because of this belief, respondents were more willing to stay in China until the completion of their studies; however, students who had completed their studies were ready to return on a priority basis. Respondents also believed that the epidemic would strongly influence the Chinese economy.

Further, most international medical students in higher degree programs were willing to stay in China compared to students enrolled in undergraduate degree programs. They were also aware of developing countries' challenges in managing their students once they return, as 14 days of isolation is required. Although the USA and UK brought their citizens back to their countries, many developing countries such as Pakistan, ${ }^{13}$ Nepal ("China defends," 2020), ${ }^{15}$ Kenya $^{16}$, and many African countries ${ }^{21}$ refused to take their students back home and advised them to stay in China. The Chinese federal and local governments cooperated and provided the best facilities to international students to keep them safe from the epidemic. The proactive initiatives taken by the Chinese government provided international students with much confidence, and they considered themselves safe in China. The risk perception among international medical students was measured when there is no vaccination available for this disease. This perception may be changed in the case once we have a vaccination for this disease.

This study's findings provide essential information for the rest of the world, as COVID-19 has become a global challenge. This study will shape public policy regarding risk management. It will also inform policymakers in two ways: the importance of risk communication to alter the public's perception. Many medical students were willing to stay in China, as evident through our findings presented in Table 4. Secondly, perceived risk characteristics should be considered in risk management decisions.

Additionally, it will help policymakers take proactive measures to manage their citizens coming from China, as medical students who have completed their degrees want to return to their home countries. They may design separate quarantine measures for students coming from China after their education. Moreover, medical students' induction into their national teams fighting COVID-19 in their home countries will help them utilize their expertise and experience from China. The study has few limitations; firstly, it was a crosssectional study. Secondly, it was conducted in one only country, that is, China. Thirdly, our sample comprised only international medical students, and it does not fully represent the international community in China. 


\section{Ethics Approval and Consent to Participate}

All the participants provided written, informed consent to participate in the study after receiving a description of the aims. The survey was set up in a way that the potential participant first read the consent/assent information and then click on a "button" in a response indicating that he/ she/they has read the consent/assent information and agrees to participate.

Confidentiality and anonymity were ensured. Instructions were given in the written form. Participants were given the right to withdraw from the study at any time, and their responses would not be included in the study. The study was approved by the ethical committee of the Fujian University of Technology. This study was conducted in accordance with the Declaration of Helsinki.

\section{Acknowledgments}

We are very thankful to Prof. Dr Vivian Yang for her valuable comments and guidance throughout this project. We are grateful to the anonymous reviewers for their valuable comments to improve the article's overall quality.

\section{Author Contributions}

All authors made substantial contributions to conception and design, acquisition of data, or analysis and interpretation of data; took part in drafting the article or revising it critically for important intellectual content; gave final approval of the version to be published; have agreed on the journal to which the article has been submitted; and agree to be accountable for all aspects of the work.

\section{Funding}

This project was supported by the Fujian Natural Science Foundation (No.2018J01648) and Development Fund of Scientific Research from the Fujian University of Technology (No. GY-S18109).

\section{Disclosure}

The authors report no conflicts of interest in this work.

\section{References}

1. World Health Organization. Coronavirus disease (COVID-2019) situation reports. Available from: https://www.who.int/emergencies/dis eases/novel-coronavirus-2019/situation-reports. Accessed May 30, 2020.
2. Sahu K, Kumar R. Current perspective on pandemic of COVID-19 in the United States. J Family Med Prim Care. 2020;9(4):1784-1791. doi:10.4103/jfmpc.jfmpc_424_20

3. Ostroff SM, Kozarsky P. Emerging infectious diseases and travel medicine. Infect Dis Clin. 1998;12(1):231-241. doi:10.1016/s08915520(05) 70420-7

4. Zimmer C. Most New York coronavirus cases came from Europe, genomes show. The New York Times. Available from: https://www. nytimes.com/2020/04/08/science/new-york-coronavirus-cases-eur ope-genomes.html. Accessed June 25, 2020.

5. Wilson ME. The traveller and emerging infections: sentinel, courier, transmitter. J Appl Microbiol. 2003;94:1S-11S. doi:10.1046/j.13652672.94.s1.1.x

6. Chinazzi M, Davis JT, Ajelli M, et al. The effect of travel restrictions on the spread of the 2019 novel coronavirus (COVID-19) outbreak. Science. 2020;pii:eaba9757.

7. Kraemer MU, Yang $\mathrm{CH}$, Gutierrez B, et al. The effect of human mobility and control measures on the COVID-19 epidemic in China. Science. 2020;pii:eabb4218.

8. Ministry of Education. Statistical report on international students in China for 2018; (April 18, 2019). Available from: http://en.moe.gov. cn/news/press_releases/201904/t20190418_378586.html.

AccessedJune 25, 2020.

9. Slovic P. Perception of risk. Science. 1987;236(4799):280-285. doi:10.1126/science. 3563507

10. Liu JT, Hammitt JK, Wang JD, et al. Valuation of the risk of SARS in Taiwan. Health Econ. 2005;14(1):83-91. doi:10.1002/hec.911

11. Wilson RS, Zwickle A, Walpole H. Developing a broadly applicable measure of risk perception. Risk Anal. 2019;39(4):777-791. doi:10.1111/risa.13207

12. Huynh TLD. Data for understanding the risk perception of COVID19 from Vietnamese sample. Data Breif. 2020;30(6):105530-105534. doi:10.1016/j.dib.2020.105530

13. Abi-Habib M. As foreigners flee China, Pakistan tells its citizens to stay; (February 11, 2020). The New York Times. Available from: https:/www.nytimes.com/2020/02/11/world/asia/china-coronaviruspakistan.html. Accessed May 30, 2020.

14. Ding Y, Du X, Li Q, et al. Risk perception of coronavirus disease 2019 (COVID-19) and its related factors among college students in China during quarantine. PLoS One. 2020;15(8):e0237626. doi:10.1371/journal.pone. 0237626

15. China defends Pak, Nepal's decision to not to evacuate their nationals from virus-hit Wuhan; (February 11, 2020). Times of India. Available from: http://timesofindia.indiatimes.com/articleshow/74083433.cms? $\mathrm{utm} \_$source $=$contentofinterest\&utm_medium $=$text\&utm_campaign $=$ cppst. Accessed May 30, 2020.

16. Zhu A. Kenyan students in Wuhan plead for evacuation; (February 5, 2020). Supchina. Available from https://supchina.com/2020/02/05/ kenyan-students-in-wuhan-plead-for-evacuation/. Accessed May 30, 2020.

17. Huynh TLD. Does culture matter social distancing under the COVID19 pandemic? Saf Sci. 2020;130:104872. doi:10.1016/j.ssci.2020.10 4872

18. Toan Luu. H. The COVID-19 risk perception: a survey on socioeconomics and media attention. Econ Bull. 2020;40(1):758-764.

19. Floyd DL, Prentice-Dunn S, Rogers RW. A meta-analysis of research on protection motivation theory. J Appl Soc Psychol. 2000;30 (2):407-429. doi:10.1111/j.1559-1816.2000.tb02323.x

20. Huynh TLD. If you wear a mask, then you must know how to use it and dispose of it Properly!": a survey study in Vietnam. Rev Behav Econ. 2020;7(2):145-158. doi:10.1561/105.00000121

21. Solomon S. 'Take us out of the country': African students plead for evacuation as coronavirus spreads; (February 11, 2020). Voice of America (VoA). Accessed May 30, 2020. 


\section{Publish your work in this journal}

Risk Management and Healthcare Policy is an international, peerreviewed, open access journal focusing on all aspects of public health, policy, and preventative measures to promote good health and improve morbidity and mortality in the population. The journal welcomes submitted papers covering original research, basic science, clinical \& epidemiological studies, reviews and evaluations, guidelines, expert opinion and commentary, case reports and extended reports. The manuscript management system is completely online and includes a very quick and fair peer-review system, which is all easy to use. Visit http://www.dovepress.com/testimonials.php to read real quotes from published authors. 